\title{
Marx meets meaning: A critical encounter between historical materialism and interpretive policy analysis A reply to Brand's State, Context, Correspondence
}

\author{
Katharina T. Paul ${ }^{1, *}$, Christian Haddad ${ }^{1}$ \\ 1 Institut für Politikwissenschaft der Universität Wien, Wien, Austria \\ * E-Mail: katharina.t.paul@univie.ac.at
}

\begin{abstract}
This article discusses historical materialist policy analysis (HMPA) as a novel approach in policy studies, and the ways in which it draws on elements of interpretive policy analysis (IPA). In our reply to Ulrich Brand's recent proposal of such an approach in this journal, we particularly discuss two aspects from a poststructuralist interpretive perspective: First, we propose that HMPA and IPA feature divergent ontologies and epistemologies that are ultimately incommensurable. Second, addressing Brand's concern with what he perceives to be a theoretical deficit in IPA, we clarify the concept of the state and its conceptual relationship to policy and policy knowledge. We conclude that, to further develop a non-functionalist policy analysis, HMPA scholarship may benefit from a more engaged reading of poststructuralist IPA.
\end{abstract}

\section{Keywords}

Policy analysis, historical materialism, interpretivism, poststructuralism, policy knowledge

\section{Historischer Materialismus und interpretative Policy-Forschung Eine Replik auf Ulrich Brand}

\section{Zusammenfassung}

Der vorliegende Kommentar bespricht die historisch-materialistische Policy-Analyse (HMPA) als einen neuen Ansatz postpositivistischer Policyforschung, der kürzlich von Ulrich Brand in dieser Zeitschrift vorgestellt wurde. Im Zentrum des Kommentars steht die Art und Weise, wie sich die HMPA auf Ansätze Interpretativer Policy Analyse (IPA) bezieht.

Dabei erarbeiten wir zwei Aspekte: Erstens diskutieren wir die ontologischen und epistemologischen Vorannahmen beider Ansätze, die wir grundsätzlich als inkommensurabel erachten. Daraus ergeben sich eine Reihe konzeptueller und methodologischer Punkte, auf die wir kurz eingehen. Zweitens diskutieren wir die Rolle des Staates in der IPA, sowie das Verhältnis von Staat, Policy und politischem Wissen im Besonderen. Mit Rückgriff auf das poststrukturalistische Spektrum der IPA erläutern wir, warum es sinnvoll ist, Policy nicht von einer Theorie des Staates her zu analysieren. Unser Kommentar schließt mit der Einschätzung, dass es einiger konzeptueller Korrekturen bedarf, um Brands Interesse an einer nicht-instrumentellen und nicht-funktionalistischen Policy-Analyse nachzukommen. Hierbei würde sich IPA als Bezugspunkt und Dialogpartner weiterhin anbieten.

\section{Schlüsselwörter}

Policy-Analyse, interpretative Policy-Analyse, historischer Materialismus; Poststrukturalismus, politisches Wissen

The authors have declared that no competing interests exist. 
In his recent contribution to the OZP, Ulrich Brand draws out the "contours of a historical materialist policy analysis" (HMPA) (Brand 2OI3). In his call to further theorize the relations between the state and policymaking, Brand introduces a double critique. On the one hand, historical materialist approaches and their common notions of policy as an outcome of social struggles stabilizing (class) relations of domination are criticized as too schematic and "functionalist", as such conceptions largely ignore the "contingencies and the internal logic of policy processes" (425). On the other hand, policy analysis, and interpretive policy analysis (IPA) in particular, is criticized for its reputed "simplified understanding of the state" (425) that falls short on adequately conceptualizing the correspondence between specific policies and broader social and political developments.

Brand's project, and the forum offered in the present journal, is a welcome initiative for academic exchange and debate concerning theoretical and methodological prerequisites of critical political science, particularly in times of academic compartmentalization and the increasingly precarious status of unconventional research programs. Brand's contribution has triggered critical responses, yet so far mainly articulated by scholars working in a materialist tradition (Bieler 20I4, Leubolt 20I4). The present discussion adds an interpretive policy studies perspective to the debate. ${ }^{\text {I }}$

We understand that Brand's main interest lies in developing an approach better suited for analyzing policy within the broader contours of a historical-materialist research framework. To this end, Brand draws on elements of interpretive policy analysis as some sort of "ancillary science" to provide a set of concepts and analytical tools. Brand, while heading in an interesting direction, unfortunately draws on IPA all too selectively to be able to reap the full benefits of IPA scholarship.

In the present review, we will discuss two aspects of Brand's deployment of IPA: The first concerns methodological prerequisites of interpretive policy analysis and its consequences for analyzing the relationships between (societal) problems and policy - one of Brand's key concerns. Second, we take up Brand's critique and discuss how poststructuralist IPA accounts for the state in policymaking, as well as the implications of this rethinking for the relationship between knowledge, policy, and the state.

\section{What we talk about when we talk about interpretation}

\author{
1.1 Discourse, meaning, and the question \\ of ontology
}

In his reflections, Brand seems to sympathize, albeit rather selectively, with some of the points put forward in interpretive policy analysis (IPA), portraying it as a "good reference point" (Brand 2013, 430) for his historical materialist policy analysis (HMPA). Acknowledging different variants within IPA (cf. Gottweis 2006), Brand suggests that poststructuralist "Foucauldian" strands of IPA are particularly apt for this endeavor. In our reading, however, Brand misreads IPA in ways that limit its usefulness for his stated purpose. First, Brand conflates the notion of discourse with societal debates, when he states that "HMPA does not refer too exclusively to knowledge, meaning, arguments, and discourses; it asks how societal reproduction functions beyond the realm of debate" (Brand 20I3, 430, emphasis added). Poststructuralist IPA does not conceive of discourse as a form of debate, nor does it limit its analysis to textual or linguistic phenomena or some sort of argumentative superstructure. Instead, its distinctive ontological feature is its view of language (and indeed other forms of symbolization) as not merely representative of "reality", but constitutive of it (Fischer/Forrester 1993; Hajer 1995; Yanow 1996; Gottweis 1998). In poststructuralist approaches, in particular, discourses are conceptualized as semiotic-material practices establishing meaning rather than as merely linguistic means of representation (Howarth 2000; Gottweis 2003).

Second, Brand seems to limit "meaning" relevant in policy merely to its (inter-) subjective form, as it appears to and is expressed by policy actors. Conversely, various strands of IPA acknowledge other conceptions, such as unconscious, tacit, as well as non-subjective meaning more akin to a Foucauldian notion of discourse (Wagenaar 20II). Third, and more generally, articulating IPA with historical materialist approaches appears to be fraught with broader methodological problems, as the two frameworks seem to operate from different ontological and epistemological presuppositions. Whereas HMPA appears to be rooted in a critical realist ontology, IPA works within a constructivist paradigm. ${ }^{2}$ If the challenge was to integrate historical materialism and IPA on an ontologi-

2 Yet, constructivist interpretive policy analysis itself is not of one kind: there are weak and strong constructivist takes in the IPA spectrum (Wagenaar 2OII, chapter 7), and there are critical realist contributions in the broader IPA community (e.g. Jessop 2OIO)
I A first draft of this article was presented in the panel discussion on "State, context, correspondence revisited" at the ÖGPW annual conference in November 20I4. We thank all participants for their contributions and Bernhard Leubolt and Thomas König for convening the panel. Furthermore, we thank Hans Pühretmayer, Jürgen Portschy, and the anonymous reviewer for comments on earlier drafts of this paper. 
cal level, we suspect that the two approaches would be reconcilable perhaps only by recourse to "weak" forms of constructivism (see Pühretmayer 2010 for a more general discussion). This is not the aim of the present review, even if such a debate might be beneficial to the advancement of critical policy studies as a whole, encompassing both HMPA and IPA. Here, we want to draw attention to the ways in which an interpretive approach, grounded in its distinctive constructivist methodology, facilitates not only a situated, reflexive, and inherently dynamic understanding of politics and policy, but also helps further elucidate the concerns articulated in Brand's piece.

\subsection{The interpretive process: from problems to problematizations}

In our reading, Brand's central concern is with the correspondence between societal reproduction and policies. Knowledge, he argues, "is crucial for the establishment of a certain correspondence between complex societal processes and policies" (435). While the relationship between social problems and policy development is intriguing, we are not certain whether the driving question should be one of correspondence. Below, we engage with this question by situating it in relation to the notion of "problematization" (cf. Rose/Miller 1992, Rabinow 2004) as part of the policy process as well as the policy analytical process.

Policy analysis as a discipline, whether conventional or critical, is essentially problem-driven: It must pay attention to and consider how actors perceive and define problems. Conventional policy analysis has focused on delivering policy solutions to apparently objective, given problems and on providing instruments to make policies more efficient such as cost/benefit analysis, decision trees, and survey research (Dye 20IO). Moving beyond such technocratic appeals, IPA provides an alternative to positivistic approaches. Following the linguistic turn in the social sciences, IPA focuses on "what is meaningful to actors" (Yanow 2007, IIO) and on how concrete problems emerge through processes of articulation and problematization. This means that objects and problems of policy are not given: There is no "actual world" (Brand 2013, 429) that policy actors could access objectively - because, in ontological terms, there is no ultimately stable and objective reality "out there" that is independent of its imagination, representation, symbolic signification, and narration (Wagenaar 20II, I38ff). It is then the task of the researcher to investigate and reflect on the meanings produced by narratives, story lines, or policy discourses (depending on which variant of IPA one is situated in) that constitute problems and objects of governance in the first place. Maarten Hajer's well-known work on acid rain provides an intriguing example of how an apparently strictly biophysical phenomenon was differently constructed with profound consequences on policymaking (Hajer 1995).

Beyond that, and in line with the argumentative turn (Fischer/Gottweis 2012), the researcher plays an active role in the construction and representation of problems: If policies function through argumentative strategies, so must policy analysis. For instance, when engaging in scientifically and technologically complex areas of policymaking, such as environmental policy and health care policy, the policy analyst will encounter a multiplicity of truth claims and competing expert opinions. The researcher can exercise reflexive distancing from her object of research, but it will not be her aim, nor within her trained social scientific skill range, to evaluate these against each other in a search for objectively definable truth. She will, however, be able to assess the discursive effect of these truth claims in evoking particular demands and identities and in informing policy discourses, policy deliberation, and ultimately policy choices and outcomes. Thus, the task of the IPA scholar is to analyze specific forms and practices of how knowledge is evaluated, their genealogies and power effect (Fischer 1999; Hajer/Wagenaar 2003, Yanow 2006).

In short, reflecting on the situated problematizations of policy is part of the interpretive process. This effort expands our notion of policy and helps policy scholars understand and explain policy problems in a more concrete and empirically rich fashion. Furthermore, this emphasis on problematizations includes a consideration of the role of the researcher in shaping the knowledge created in the research process. This does not, however, lead to a hopelessly subjectivist mode of knowledge production, but, if done thoroughly and systematically, to a more plausible, robust form of "situated knowledge" (Harraway 1988), providing a "narrative form of explanation" (Bevir/Rhodes 2006, 20-30).

These considerations concerning the role of problematization in both policy practice and policy analysis bear important consequences for Brand's concerns regarding the need for correspondence between "problems" and "policy". From an interpretive perspective, a clear distinction between problems and policy collapses. Therefore, we find it difficult to perceive of their relationships in terms of correspondence, as it evokes a functionalist model. If new articulations of historical materialist policy approaches are to account for the relationship between problems and policy in a non-functionalist way - as Brand intends to (Brand 2013, 426) we suggest a reorientation towards problematizations. Problems are then not prior to policy, but both are "coconstructed" in processes of problematizations.

This proposition, in turn, raises questions concerning the conceptualization of "policy knowledge". Brand attempts to approach this question through the notion 
of the state as knowledge apparatus. Let us consider this more carefully in the remainder of this article.

\section{The State: indigestible meal, forceful reality?}

In his discussion, Brand states "both [IPA and HMPA] claim that the state $[. .$.$] is not at the center of control of$ modern societies, and both are skeptical with respect to the steering capacities of policies, because [their] objects [...] tend to have their own logics" (Brand 2013, 430). He then proceeds to charge IPA with "deficits in [...] state theory" (425). In light of the ontological and epistemological differences between HMPA and IPA discussed above, this is hardly surprising. Indeed, IPA has effectively developed against the conceptual turn form government to governance, decentering the state as the principal framework shaping social and political life (Mayntz/ Scharpf 1995; Rhodes 1996; Pierre/Peters 2000; Hajer/Wagenaar 2003). Against this general debate, and Brand's specific endeavor, it is intriguing to assess the notion of the state - and the utility of state theory in particular - with regard to critical policy studies.

\subsection{The state as content or context of policy?}

While in general embracing many of its insights, Brand argues that IPA suffers from a "simplified understanding of the state" (Brand 20I3, 425). Hence, a HMPA grounded in state theory may provide a "more sophisticated understanding of the very concept of 'policy', as well as the context of policy" (430). In this view, the state should be considered as relevant context and structural prerequisite of policy. Brand asserts that while "meaning given to context by particular actors or groups is important, $[\ldots]$ the context is also reproduced independently of that meaning" (433). Brand wishes to remedy these reputed shortcomings in IPA by way of introducing a notion of the state as "knowledge apparatus".

For Brand's purpose, the Foucauldian current of IPA may constitute a useful resource. Yet a recourse to Foucault is intricate in this context, not only because both HMPA and IPA draw selectively on Foucault, but precisely because his work has given rise to different appraisals of the state. Perhaps IPA broadly identifies with Foucault's 1978 stance that state theory amounts to an indigestible meal one cannot but abstain from (Foucault 2008,77 ). In this context, Foucault has suggested a threefold relocation of analytical scrutiny that has built the basis for an "analytics of government" (cf. Dean 20I0): from object (for instance, a predefined policy problem) to practices that constitute it; from institution (such as "the state") to the technologies deployed in its operation; from functions (of an object, policy) to their strategic movements and catenations in protracted power strug- gles (Foucault 2007, II5ff, Lemke 2007). This approach has been taken up quite suitably within IPA (see Gottweis 2003; Wagenaar 2011, IO7-I37).

In his later work, Foucault (1982) reasserts the centrality of the state in the organization of power, which has recently led to a revitalization of state theory (Lemke 2007; Jessop 20IOb). Notwithstanding this recent reappraisal, one should not confuse an accentuated analytical emphasis on the state with a reaffirmation of state theory with its totalizing and at times structuralist connotations. Foucault's reassessment should be regarded as the outcome of a genuinely genealogical endeavor that retains a focus on problematizations and practices of government. In short, the state may be the contingent stabilization and outcome of a complex strategic power constellation (Lemke 2007). We understand that HMPA is interested in analyzing how structures emerge through struggles and how structured ensembles, in turn, affect politics and policy. Yet the structuralist elements in the notion of the state, as is currently introduced in HMPA (Brand 2013, 432), limit an empirical analysis of both policy content and context - inasmuch as these are analytically separable at all.

With a focus on policy we suggest that structured ensembles - or dispositifs, to use the Foucauldian concept - figure differently in policies such as environmental, health care, or migration. More precisely: while "the state" may be a central dispositif in all policies, what exactly the state is, which condensed forces and powerrelations are operative, etc. is ultimately an empirical question to be tackled in any respective policy. It is part of the interpretive task of the policy scholar to explore and carve out what contexts are operative, how they are constituted and demarcated as contexts, and whether and to which extent they shape and structure policy.

At this point, HMPA scholars might object that not all contexts are transparent to policy actors, "working behind their backs", as Marx would put it. This exposes perhaps a key difference between HMPA and IPA. While HMPA theoretically presupposes these tacit contexts in order to facilitate analysis, IPA seeks to render them visible through a range of interpretive strategies. These methodologies have proven particularly suitable in studying the interplay of content and context of policy. As, for instance, studies of biotechnology policy have demonstrated, struggles over the concrete content of a policy are closely intertwined with problematizations and struggles over its context: which institutional procedures should apply, what forms of property law are desirable and applicable for biotechnology, which institutions are deemed legitimate and competent to assume authority in regulatory processes, etc. (Gottweis 1998; Jasanoff 2005; Gottweis/Salter/Waldby 2008). It is against this background that Herbert Gottweis suggested that, in post-positivist policy analysis, content and 
context have to be studied in one and the same analytical strategy (Gottweis 2003).

\subsection{Knowledge, policy, and the state}

In the analysis of the struggle over content and context, positivist policy analysis would focus on expert knowledge as the politically salient and most authoritative form of knowledge. Here, IPA and HMPA would most likely converge in an effort to overcome an exclusive reliance on expert knowledge and its functionalist and positivist bias in conventional policy analysis, and to facilitate more democratic and participatory forms of generating policy knowledge. Acknowledging the importance of knowledge for policymaking and governance, Brand suggests "the state needs to constantly create knowledge [...] through its own activities, lobbyists, think-tanks, etc." (435). The main issue for Brand, however, appears to be condensed in the question of how the state knows the demands, requirements, and the knowledge necessary to deal with societal problems (ibid.). Apart from the difficulties we find with the realist appeals of this problematic (as if societal problems were given and understood independently of the constructions and problematizations of "the state"), we are puzzled by such a strong catenation and identification of state and policy, particularly with respect to knowledge.

To be sure, IPA and HMPA share an interest in how certain articulations of power and knowledge become hegemonic - Brand adds: "become state policy" (433). But to map these struggles over appropriate and plausible forms of knowledge on the conceptual terrain of the state appears of rather limited utility. Take the example of HIV/AIDS patients in the I980s. The emergence of AIDS treatment activists as a heterogeneous social movement creating and renegotiating knowledge in a broad variety of settings and practices went hand in hand with processes of becoming credible "lay experts" (Epstein 1996). It was in the course of these struggles that certain practices and forms of lay expertise were effectively translated into the institutionalized routines of biomedical regulation, legislative committees, and policies - "they became state".

To understand the emergence and effects of policy it is therefore important to conceptualize policy as relatively autonomous from the state, taking place in a broad variety of heterogeneous sites and spaces. IPA scholars would start by analyzing the very specific sites and practices of knowledge production and, inseparably, the struggles over interpretation - that is to say, the meaning of knowledge - before analyzing its selective translation into the knowledge apparatuses of the state (Barry 200I). It is certainly possible to integrate heterogeneous entities such as private research laboratories, patient advocacy groups, or libertarian think tanks into an extended concept of an integral state. Yet we suspect that this would constrain, rather than enrich, an analysis of which actors, forces, and discourses manage to "become state" in the course of struggles, how competing articulations of knowledge and authority are temporarily stabilized and become institutionalized in concrete substantive policies. In contrast, to facilitate a more comprehensive empirical analysis of this process, post-positivist policy analysis has broadened the notion of policy beyond its mainstream connotation - that is, beyond what Brand refers to as "the concrete framework for the implementation of institutionalized politics" (Brand 20I3, 426). This conceptual premise has helped reconceptualize the relationship between policy and knowledge in more dynamic and multidirectional terms, as reflected in the vast range of empirical studies conducted in an interpretive framework (Howarth/ Norval/Stavrakakis 2000; Yanow/Schwartz-Shea 2006; Fischer/Gottweis 2012; Griggs/Norval/Wagenaar 20I4).

\section{Conclusions}

Brand's project and the resulting debate expose both strengths of interpretive policy analysis and its incommensurability with historical-materialist state theory. HMPA is at this point still in its infancy, and shares with IPA the objective to promote a critical project in policy analysis and in overcoming positivism. Yet the tenets and skills developed in and through IPA scholarship are, in our view, insufficiently considered by Brand, not least because they appear at odds with historical materialism. It seems that Brand's main interest in IPA consists in its role as some sort of "ancillary science" to compensate for blind spots in historical materialism. This instrumental interest in only particular elements of IPA may explain what we perceive as a selective reading of some of the basic premises of IPA scholarship. While IPA certainly may provide valid tools for his endeavor to open up the black box of policy in historical materialism and to overcome its functionalist overtones, the HMPA approach, in our view, does not go far enough.

In the present discussion, two aspects have been particularly salient. First, the poststructuralist variant of IPA presented here is committed to an interpretive, empirically grounded approach to policy analysis with a particular ontological and epistemological stance. Interpretivism enhances policy analysis to the effect that it helps the researcher focus on the production of meaning as it develops under particular contingent, but always emerging power struggles. Moreover, while problems are at the core of policy, problems per se are not given. Epistemologically speaking, it is impossible for both policy makers and policy scholars to access empirical phenomena in a direct and unmediated fashion. Conse- 
quently, in its methodology, IPA focuses on problematizations, rather than problems. In addition, IPA scholars consider their own problematizations and reflect on how specific problem articulations and the selective deployment of concepts shape the research process and the very problematization at hand - and thus, in some instances, policy knowledge. In its departure from positivist policy analysis, IPA enables the researcher to explore "policy", broadly understood, in more situated and insightful ways. The second part of our discussion of Brand's proposal focused on the concept of the state in policy analysis and its relation to policy knowledge. As part of its research program, IPA has come to gradually dismiss the state not as a powerful social reality, but as the central organizing concept. Importantly, this shift has entailed a focus on exploring practices that articulate policy, knowledge and the state, rather than identifying state and policy, thereby subsuming policy knowledge under apparently given institutional frameworks of the state.

While the debate that has unfolded in the OZP presents a useful opportunity to advance our understanding of policy, IPA and HMPA as currently presented by Brand, appear incommensurable in various respects. Nevertheless, and given this timely opportunity for a critical exchange between IPA and HMPA, it would be worthwhile to evaluate - and perhaps even "triangulate" - empirical findings produced by IPA and HMPA in the years to come. Such a research program, we expect, will produce further material for a critical yet constructive dialogue between IPA and HMPA.

\section{References}

Barry, Andrew (200I). Political Machines: Governing a Technological Society, London.

Bevir Mark/Rod Rhodes (2006). Governance Stories, London and New York.

Bieler, Andreas (2014). What about class struggle? Critical reflections on Uli Brand's HMPA, in: Austrian Journal of Political Science (OZP), Vol. 43(3), 305308.

Brand, Ulrich (2013). State, context and correspondence. Contours of a historical-materialist policy analysis, in: Austrian Journal of Political Science (OZP), Vol. 42(4), 425-442.

Dean, Mitchell (20IO). Governmentality: Power and Rule in Modern Society, Second edition, Los Angeles and London.

Dye, Thomas (2010). Understanding Public Policy, New Jersey.

Epstein, Steven (1996). Impure Science. AIDS, activism, and the politics of knowledge, Berkeley and Los Angeles.
Fischer, Frank (1999). Technological deliberation in a democratic society: The case for participatory inquiry, in: Science and Public Policy, Vol. 26(5), 294302.

Fischer, Frank/Herbert Gottweis (eds.) (2012): The Argumentative Turn Revisited. Public Policy as Communicative Practice, Durham and London.

Fischer, Frank/John Forester (eds.) (1993). The argumentative turn in policy analysis and planning, Durham, NC.

Foucault, Michel (2007). Security, Territory, Population. Lectures at the College de France 1977-78, Houndsmill and New York.

Foucault, Michel (2008). The Birth of Biopolitics. Lectures at the Collège de France 1978-79, Houndsmill and New York.

Foucault, Michel (1982). The Subject and Power, in: Critical Inquiry, Vol. 8(4), 777-795.

Rhodes, Rod (1996). The new governance: Governing without Government, in: Political Studies, Vol. 44, 652-67.

Gottweis, Herbert (1998). Governing Molecules: The Discursive Politics of Genetic Engineering in Europe and the United States, Cambridge.

Gottweis, Herbert (2003). Theoretical strategies of poststructuralist policy analysis. Towards an analytics of government, in: Maarten Hajer/Hendrik Wagenaar (eds.): Deliberative Policy Analysis. Understanding Governance in the network society, Cambridge, 247265.

Gottweis, Herbert (2006). Constructivist Approaches to Public Policy, in: Jon Pierre/Guy Peters (eds.): Public Policy Handbook, London, I- I9.

Gottweis, Herbert/Brian Salter/Catherine Waldby (2009). The global politics of human embryonic stem cell research, Houndsmill.

Griggs, Steven/Aletta Norval/Hendrik Wagenaar (2014). Practices of Freedom. Decentred Governance, Conflict and Democratic Participation, Cambridge.

Hajer, Maarten (1995). The Politics of Environmental Discourse. Ecological Modernization and the Policy Process, Oxford.

Hajer Maarten/Hendrik Wagenaar (eds.) (2003). Deliberative Policy Analysis. Understanding Governance in the Network Society, Cambridge.

Harraway, Donna (1988). Situated Knowledges: The Science Question in Feminism and the Privilege of Partial Perspective, in: Feminist Studies, Vol. I4(3), 575-599.

Howarth, David (2000). Discourse, Buckingham and Philadelphia.

Howarth, David/Aletta Norval/Yannis Stavrakakis. (eds.) (2000). Discourse Theory and Political Analysis. Identities, Hegemonies and Social Change, Manchester. 
Jasanoff, Sheila (2005). Designs on Nature. Science and Democracy in Europe and the United States, Princeton.

Jessop, Bob (20I0a). Cultural political economy and critical policy studies, in: Critical Policy Studies, Vol. 3 (34), 336-356.

Jessop, Bob (2OIOb). Constituting another Foucault effect. Foucault on States and Statecraft", in: Ulrich Bröckling/Susanne Krasmann/Thomas Lemke (eds.): Governmentality. Current Issues and Future Challenges, London and New York, 56-73.

Lemke, Thomas (2007). Eine unverdauliche Mahlzeit? Staatlichkeit, Wissen und die Analytik der Regierung, in: Susanne Krasmann/Michael Volkmer (eds.): Michel Foucaults "Geschichte der Gouvernementalität" in den Sozialwissenschaften, Bielefeld, 47-73.

Leubolt, Bernhard (2014). History, institutions, and selectivities in historical-materialist policy analysis: A sympathetic critique of Brand's State, context and Correspondence, in: Austrian Journal of Political Science (OZP), Vol. 43(3), 309-318.

Mayntz, Renate/Fritz Scharpf (1995). Gesellschaftliche Selbstregelung und politische Steuerung, Frankfurt.

Pierre, Jon/Guy Peters (2000). Governance, Politics and the State, New York.

Pühretmayer, Hans (2010). Zur Kombinierbarkeit von Critical Realism und Poststrukturalismus: Eine Reformulierung der Struktur-Handlungs-Frage, in: Austrian Journal of Political Science (OZP), Vol. 39(I), 9-26.

Rabinow, Paul (2004). Was ist Anthropologie?, Frankfurt. Rose, Nikolas/Peter Miller (1992). Political Power beyond the State: Problematics of Government, in: British Journal of Sociology, Vol. 43(2), 173-205

Yanow, Dvora (1996). How Does a policy mean? Interpreting Policy and Organizational Actions, Washington D.C.

Yanow, Dvora (2007). Interpretation in policy analysis: On methods and practice, Critical Policy Studies, Vol. I(I), IIO-I 22.

Yanow, Dvora/Peregrine Schwartz-Shea (eds.) (2006). Interpretation and Method: Empirical Research Methods and the Interpretive Turn, Armonk, NY and London.

Yanow, Dvora (2006). Conducting Interpretive Policy Analysis, Newbury Park.

Wagenaar, Hendrik (2OII). Meaning in Action. Interpretation and Dialogue in Policy Analysis, London.

\section{Authors}

Katharina T. Paul is a Lise Meitner Research Fellow (Austrian Science Fund, FWF) at the University of Vienna. She holds a PhD from the University of Amsterdam and was formerly an assistant professor at Erasmus University Rotterdam. Her research interests are at the intersection of political science and the sociology of science and technology.

Christian Haddad has been working as a researcher and lecturer in political science at the University of Vienna. Currently Haddad is finishing his Ph.D. thesis on the biopolitics of innovation in biomedical research policy. His research interests are at the intersection of political theory, critical policy studies, and the sociology of science and technology. 